\title{
Industrial Policy, Industrialization and Economic Development of Kyrgyzstan
}

\author{
Euna Lee ${ }^{1} \&$ Jai S. Mah ${ }^{2}$ \\ ${ }^{1}$ Seoul National University, Seoul, South Korea \\ ${ }^{2}$ Ewha Womans University, Seoul, South Korea \\ Correspondence: Jai S. Mah, Division of International Studies, Ewha Womans University, Seodaemun-gu, Seoul \\ 03760, South Korea. Tel: 82-2-3277-4683. E-mail: jsmah@ewha.ac.kr
}

Received: May 28, $2020 \quad$ Accepted: June 11, $2020 \quad$ Online Published: August 31, 2020

doi:10.5539/ass.v16n9p41 URL: https://doi.org/10.5539/ass.v16n9p41

\begin{abstract}
Kyrgyzstan pursued the market-based reform in the process of transition. Based on the literature review and statistical data covering 1990s-2010s, this paper explains economic development and industrialization of Kyrgyzstan in its transition process. The government of Kyrgyzstan promoted several priority sectors including agriculture, mining, energy, garment and agro-processing industry by industrial policy measures. There is little evidence that Kyrgyzstan has a comparative advantage in agriculture. Gold mining is expected to be depleted by 2020s. Kyrgyzstan appears to be competitive in hydroelectricity generation and agro-processing industry. Although the garment industry has led the manufacturing sector, it has been losing the foreign investors' attention. Therefore, it is necessary for Kyrgyzstan to think of the next stage of economic development with the new industrial-led economic development strategy. The government of Kyrgyzstan may benefit from promoting value-added industries. For such value-added industries to develop, strengthening infrastructure particularly in human capital would be critical.
\end{abstract}

Keywords: industrialization, industrial policy, economic development, Kyrgyzstan

\section{Introduction}

Kyrgyzstan is one of the countries belonging to the Former Soviet Union (FSU). After the disintegration of the Soviet Union in December 1991, FSU countries came into place and followed either the shock therapy or the gradualist approach in the transition from a centrally-planned to a market-based economy (Pak, 2016, pp. 27-28; Bae \& Mah, 2019). The majority of FSU countries accepted the shock therapy (Svejnar, 2002: 5-6). Kyrgyzstan chose shock therapy and pursued rapid market-based reform. It showed great support for the Washington Consensus and became the first country among the FSU countries to join the World Trade Organization (WTO) (Appel, 2004, p. 98). As such, Kyrgyzstan could be regarded as a country which pursued market-based reform most actively among the transition economies in Central Asia during the 1990s. Despite its rapid transition to the market economy, Kyrgyzstan experienced severe depression right after the independence. The annual average real GDP growth rate during 1993-1995 equaled -13.7 percent. Per capita GDP at current prices fell from US\$492 in 1992 to US\$257 in 1999 (United Nations Conference on Trade and Development (UNCTAD), 2019).

Kyrgyzstan began to recover since the late 1990s. The government of Kyrgyzstan prioritized several sectors in its economic development process, which comprise of agriculture, gold mining, energy, garment and agro-processing industry (National Council for Sustainable Development of the Kyrgyz Republic (NCSD), 2013: 5). Despite the government's effort to promote these priority sectors, due to numerous limitations such as insufficient investment, infrastructure, and human capital, these priority sectors still lack capacity for further growth (Uzagalieva, 2003; Niazaliev, 2004; Komendantova et al., 2018a). Thus, Kyrgyzstan needs to sharpen the direction of its industrial policy.

This paper explains economic development and industrialization of Kyrgyzstan in its transition process mainly using the literature review and statistical data covering the period 1990s-2010s. The structure of this paper is as follows. Section 2 briefly summarizes the transition approaches of the FSU countries and the overall economic development of Kyrgyzstan. Section 3 explains the direction of the industrial policy of Kyrgyzstan. The evolution and current state of major industries of Kyrgyzstan are explained in Section 4. Section 5 provides 
policy implications drawn from the experiences of industrialization and industrial policy of Kyrgyzstan. Conclusions are provided in Section 6.

\section{Transition and Economic Development of Kyrgyzstan}

FSU countries differ significantly in the degree of transition to the market economy. Table 1 shows the transition indicators developed by the European Bank for Reconstruction and Development (EBRD). The value shown in Table 1 is the average of the six assessment criteria: large scale privatization, small scale privatization, governance and enterprise restructuring, price liberalization, trade and foreign exchange system, and competition policy. The measurement scale ranges from 1 to $4+; 1$ as "little or no change from a rigid centrally planned economy" and 4+ as "the standards of an industrialized market economy" (EBRD, 2019: para. 8). In 1994 Estonia, Lithuania, Latvia and Kyrgyzstan exceeded the score of 3; while most of the others scored near 1.5 and 2 (EBRD, 2014). As Table 1 shows, among the transition economies in Central Asia, Armenia, Georgia and Kyrgyzstan were the forerunners of the market-based reform. Meanwhile, Turkmenistan and Uzbekistan took the gradualist approach in transition. Kyrgyzstan belongs to one of the poorest countries among the transition economies in Central Asia. Its GDP per capita equaled US\$1,251 in 2017 (UNCTAD, 2019).

Table 1. Transition Indicators of FSU Countries, 1992-2014s

\begin{tabular}{cccccccccc}
\hline & 1992 & 1995 & 1998 & 2001 & 2004 & 2007 & 2010 & 2013 & 2014 \\
\hline Armenia & 1.7 & 2.4 & 2.9 & 3.2 & 3.4 & 3.5 & 3.5 & 3.4 & 3.4 \\
Azerbaijan & 1.3 & 1.9 & 2.7 & 2.7 & 2.9 & 2.9 & 2.9 & 2.9 & 2.9 \\
Georgia & 1.4 & 2.3 & 3.3 & 3.3 & 3.3 & 3.5 & 3.5 & 3.5 & 3.5 \\
Kazakhstan & 1.4 & 2.5 & 3.2 & 3.1 & 3.1 & 3.1 & 3.1 & 3.1 & 3.1 \\
Kyrgyzstan & 1.7 & 3.2 & 3.2 & 3.3 & 3.4 & 3.4 & 3.4 & 3.4 & 3.4 \\
Tajikistan & 1.4 & 2.1 & 2.5 & 2.7 & 2.7 & 2.8 & 2.9 & 3.0 & 3.0 \\
Turkmenistan & 1.0 & 1.4 & 1.7 & 1.4 & 1.4 & 1.7 & 1.7 & 1.8 & 1.8 \\
Uzbekistan & 1.3 & 2.6 & 2.3 & 2.3 & 2.2 & 2.3 & 2.3 & 2.3 & 2.3 \\
\hline
\end{tabular}

Source: European Bank for Reconstruction and Development, Transition Indicators, 2014.

Right after the transition, most of the FSU countries experienced severe decline in national income, due to the disintegration of the Soviet Union that had been highly integrated internally (Linn, 2004: 5). Meanwhile, Uzbekistan, for instance, who chose the gradualist approach in the process of transition, did not experience severe depression during the 1990s (Bae \& Mah, 2019). Kyrgyzstan and most of the other transition economies who took the big bang approach experienced more severe negative economic growth and in general, took a longer time for them to reach the GDP level at the times right before the independence. Kyrgyzstan was able to recover its GDP level of 1992 by the year 2004 (UNCTAD, 2019).

The government of Kyrgyzstan undertook deregulation right after the independence. Due to the sudden deregulation of prices, Kyrgyzstan experienced hyperinflation. That is, inflation rates of 1992 and 1993 jumped to 2,038 percent and 1,336 percent, respectively (Uzagalieva, 2003, p. 25). Before 1993, it was still one of the ruble countries, so it could not pursue autonomous macroeconomic policies to correct hyperinflation (Niazaliev, 2004, p. 69). As a way to stabilize inflation rates, it introduced its own national currency, the som, in 1993 and implemented contractionary macroeconomic policy in line with the recommendations of the International Monetary Fund (IMF) (Dabrowski \& Antczak, 1994, p. 8). Inflation rates fell since the mid-1990s.

Kyrgyzstan experienced serious depression right after the independence. One of the major economic problems that Kyrgyzstan was facing during the time of independence was its high dependence on the FSU countries (Dabrowski \& Antczak, 1994, pp. 2-4). Kyrgyzstan began to recover, as the annual average real GDP growth rate reached 6.8 percent during 1996-1998 and 3.8 percent during 1996-2017. Table 2 shows the composition of GDP of Kyrgyzstan by sector. The share of agriculture, fisheries and forestry reached 40.3 percent in 1995, but it continued to decrease since 1997 , reaching 12.3 percent in 2017 . The share of services rose during the 2000s and 2010s, reaching 50.4 percent in 2017. That of the industrial sector fluctuated during the 1990s and then dropped to 20 percent in 2005. Since then, it increased to over 25 percent of GDP during the 2010s. This shows diversification of Kyrgyzstan's economic structure since the late 2000s (NCSD, 2013: 53; Komendantova et al., 2018a: 10). ${ }^{1}$

\footnotetext{
${ }^{1}$ Despite the decreasing share of agriculture, fisheries and forestry in GDP, the primary sector is still important in Kyrgyzstan in the sense that considerable population of Kyrgyzstan live in it. Over 20 percent of the employed population
} 
Table 2. GDP by Sector in Kyrgyzstan, 1991-2017 (unit: percent of GDP)

\begin{tabular}{cccc}
\hline year & agriculture, fishing and forestry & industry $^{+}$ & services \\
\hline 1991 & 35.3 & 33.8 & 26.3 \\
1995 & 40.7 & 18.1 & 35.6 \\
2005 & 28.5 & 20.0 & 42.4 \\
2010 & 17.4 & 26.3 & 49.3 \\
2015 & 14.1 & 25.1 & 52.1 \\
2017 & 12.3 & 26.5 & 50.4 \\
\hline
\end{tabular}

$+\quad$ includes construction

Source: World Bank, World Development Indicators, 2018

Table 3 shows the changing pattern of the main export products of Kyrgyzstan. Exports of food products increased over time, reaching US\$181 million in 2017, which is more than 10 percent of the total exports. Exports of non-food raw materials exceeded US\$.2 billion each year in 2016 and 2017, comprising more than 10 percent of the total exports. Exports of fuel, lubricating oil and others continued to be over US\$.1 billion during 2006-2014, peaking US\$.4 billion in 2008, which is over 20 percent of the total exports of Kyrgyzstan. The exports of fuel and others, however, decreased since then and recorded US\$87 million in 2017. Exports of industrial goods, machinery and transport equipment increased during the 2010s, amounting to US\$319 million in 2017, which shared 18 percent of total exports. Exports of machinery and transport equipment increased particularly during the 2010s. By trade partner, Kyrgyzstan's trade with China increased by leaps and bounds since the mid-2000s. For instance, the former's import from the latter increased from a mere US\$8 million in 2002 to US\$5.4 billion in 2014 (Observatory of Economic Complexity (OEC), 2015).

Table 3. Main Export Products of Kyrgyzstan

(unit: US\$ million)

\begin{tabular}{llllll}
\hline products & 1998 & 2005 & 2010 & 2015 & 2017 \\
\hline food products and live animals & 40 & 57 & 161 & 174 & 181 \\
non-food raw materials & 45 & 76 & 53 & 72 & 245 \\
mineral fuel, lubricating oils and others & 29 & 79 & 118 & 84 & 87 \\
industrial goods & 50 & 86 & 58 & 75 & 107 \\
machinery and transport equipment & 63 & 51 & 87 & 187 & 212 \\
total & 535 & 674 & 1760 & 1483 & 1764 \\
\hline
\end{tabular}

Source: National Statistical Committee of the Kyrgyz Republic, 2018.

\section{Industrial Policy of Kyrgyzstan}

\subsection{Overall Direction of Industrial Policy}

The government of Kyrgyzstan has tried to promote several sectors by the provision of tax incentives as well as infrastructure, among others. For instance, it has provided tax incentives to the gold mining sector. The garment industry has been provided with tax incentives and infrastructure since the 2010s.

The garment industry could be considered as the leading industry in the manufacturing sector in Kyrgyzstan (International Labor Organization (ILO), 2012: 1). Indeed, Kyrgyzstan's textile, garment and related production accounted for 95 percent of manufacturing's GDP in 2018. Kyrgyzstan has a comparative advantage in the labor-intensive industry due to its low wage level. The low labor cost, however, has a disadvantage because it is accompanied by low labor productivity (Rovenskaya et al., 2018: 10, 22). Despite such a weakness of the garment industry, the government still identifies it as one of the priority sectors, and has implemented several programs to promote the industry due to its contribution to economic development and its comparative advantage in the labor-intensive industries (Organization for Economic Co-operation and Development (OECD), 2014: 34; Rovenskaya et al., 2018: 22).

The government of Kyrgyzstan has identified the agro-processing industry together with the garment industry as one of the industries to lead the manufacturing sector. During the 1990s, the privatized enterprises did not have technology, adequate management skills, understanding of the market, and proper equipment. As a result, the

was working in the agricultural sector as of 2017 (National Statistical Committee of the Kyrgyz Republic (NSC), 2018). 
quality of the products belonging to the agro-processing industry was poor and did not meet internationally required standards (World Bank, 1998: 16). Kyrgyzstan did not even have an agricultural product certifying system that reaches international standards. During the mid-2010s, the government's policy focused on the better supply of agricultural equipment, infrastructure and financial means to encourage more efficient production, and creation of training and education programs regarding the use of modernized technology in the agro-processing industry (NCSD, 2013: 86, 88). The government aims to provide state support for the agro-processing industry during 2018-2022 (Development Partners' Coordination Council (DPCC), 2018: 32).

\subsection{Tax Incentives}

The government of Kyrgyzstan has provided tax incentives to certain industries such as gold mining, garment and agro-processing industry. For instance, it granted very generous tax benefits to the investors investing in the mining sector. In the case of the most important gold mine in Kyrgyzstan, Kumtor mine, corporate profit tax was exempted for five years. Along with the unrealized dividend from the government's equity share in the gold mining sector, generous tax concession aggravated the government's tax revenue (World Bank, 2002: 26). In 2004, the government terminated the generous tax concessions that had been granted to Kumtor company (World Trade Organization (WTO), 2014: 92). Garment manufacturing enterprises have been subjected to the so-called patent-based taxation which significantly lessened their tax burden since 2005. Under the patent-based taxation in the garment industry, manufacturers pay their taxes based on the number of workplaces, not according to the value of production. The government decided to cancel the patent-based tax system in 2008, but it was introduced again (ILO, 2012: 13-14; Jenish, 2014).

To promote the agro-processing industry, the government has provided subsidies in the form of reimbursing interests on investment loans that were used to purchase machines, to repay lease, and to expand the scope of equipment that can be leased by the firms in the agro-processing industry (NCSD, 2013: 90). The government plans to develop new financial instruments for the export promotion of the agro-processing industry and provide more active support for the leasing of machines (DPCC, 2018: 33-34).

\subsection{FDI Policy}

The overall direction of FDI policy of Kyrgyzstan is a pursuit of an open FDI regime with some entry limitations (UNCTAD, 2016: 6; Komendantova et al., 2018b: 9). It does not impose restrictions on FDI flows into most of the key sectors, including all the above-mentioned priority sectors (UNCTAD, 2016: 6-7). To attract FDI, in the National Sustainable Development Strategy for 2013-2017, the government emphasized the importance of transparent and well-functioning legislation that can guarantee stability in making an investment in Kyrgyzstan by eliminating corruption, protecting private property rights and maintaining stable financial system. It also aimed to strengthen infrastructure (NCSD, 2013: 65).

The annual average amount of FDI flows into Kyrgyzstan equaled less than US\$.1 billion during 1995-2004, as shown in Table 4. It increased since the mid-2000s. FDI inflows increased rapidly during the 2010s, reaching an annual average amount of US\$.6 billion during 2015-2017. Reflecting such a significant increase in the amount of FDI inflows during the 2010s, the ratio of FDI inflows/GDP rose to 7.3 percent during 2010-2014. Kyrgyzstan established Investment Promotion Agency (IPA) in 2014 to promote investment in the country and to establish a more friendly relationship with foreign investors. It introduced the National Investment Promotion Strategy in the same year (OECD, 2018: 137). Reflecting such an active government policy to attract FDI, FDI flows into Kyrgyzstan reached US\$1.1 billion in 2015 and US\$.6 billion in 2016, while it fell somewhat in 2017. Consequently, the ratio of FDI inflows/GDP rose to 9.3 percent during 2015-2017. FDI inflows expressed in terms of stock increased from US\$.4 billion in 2000 to US\$1 billion in 2007 and then to US\$5.5 billion in 2017 (UNCTAD, 2019). Such findings from the data show that Kyrgyzstan has succeeded in attracting FDI during the 2010s.

Table 4. FDI Flows into Kyrgyzstan, 1995-2017 (annual average)

(unit: US\$ million, \%)

\begin{tabular}{ccc}
\hline Year & FDI Inflows & FDI inflows/GDP \\
\hline $1995-1999$ & 75.9 & 4.8 \\
$2000-2004$ & 45.7 & 2.2 \\
$2005-2009$ & 191.8 & 5.0 \\
$2010-2014$ & 459.6 & 7.3 \\
$2015-2017$ & 617.2 & 9.3 \\
\hline
\end{tabular}

Source: UNCTAD, Data Center, 2019. 
By sector, FDI flows into agriculture, fisheries and forestry remained trivial, as is shown by Table 5. The implication is that agriculture appears not to be attractive from foreign investors' viewpoint. The mining sector shared around 10 percent of FDI inflows. The share of the manufacturing sector in FDI inflows continued to be around 30 to 50 percent during 2000-2017. During 2015-2017, its share remained between 30 and 36 percent.

Table 5. FDI inflows by Sector (unit: US\$ million)

\begin{tabular}{ccccccc}
\hline \multirow{2}{*}{ year } & \multicolumn{5}{c}{ sector } \\
\cline { 2 - 7 } & AFF $^{\mathrm{a})}$ & mining \& quarrying & manufacturing & EGW $^{\mathrm{b})}$ & others & total \\
\hline 2000 & 0.0 & 4.6 & 44.0 & 0.0 & 40.9 & 89.6 \\
2003 & 2.0 & 12.3 & 73.2 & 0.3 & 59.2 & 147.0 \\
2006 & 3.6 & 55.8 & 141.0 & 0.0 & 135.2 & 335.6 \\
2009 & 0.0 & 6.4 & 166.5 & 0.9 & 487.1 & 660.9 \\
2012 & 2.0 & 27.8 & 255.1 & 0.0 & 305.7 & 590.7 \\
2015 & 0.3 & 14.7 & 564.7 & 136.7 & 856.8 & 1573.2 \\
2016 & 0.2 & 54.3 & 251.2 & 122.2 & 386.0 & 814.0 \\
2017 & 0.0 & 81.0 & 186.3 & 79.8 & 269.6 & 616.8 \\
\hline
\end{tabular}

a) agriculture, fisheries and forestry

b) production and distribution of energy, gas and water

Source: National Statistical Committee of the Kyrgyz Republic (2018). Official Statistics. Retrieved from http://stat.kg/en/statistics/selskoe-hozyajstvo/

Of the manufacturing sector, the garment industry is one of the prioritized sectors in attracting FDI (OECD, 2018: 137). In 2013, the amount of FDI flows into the garment industry reached its peak, recording US $\$ 10.4$ million. In 2016, however, it declined significantly to US\$0.7 million and only 23 garment enterprises received investment from foreign investors. Most of the other garment firms relied on their own capital and commercial bank lending (Komendantova et al., 2018a: 15). FDI flows into the garment sector remained only a few percent of those into the manufacturing sector as a whole in the mid-2010s. Low electricity and labor cost, and extensive knowledge of the garment market from the bazaar transaction are advantageous factors that can lead to further FDI flows into the garment industry. However, the problems with the garment industry in attracting FDI are that the industry is not equipped with proper infrastructure and skilled laborers (UNCTAD, 2016: 34-35).

FDI flows into the agro-processing industry in Kyrgyzstan remained quite low during the 1990s, which could be attributed to the government's placing of excessive regulations on the establishment of joint ventures in the industry. For instance, it required 69 permits for a joint venture to start its dairy business. Such excessive regulations worked as a disincentive to foreign investors' investment in Kyrgyzstan's agro-processing industry. Furthermore, in the 1990s and 2000s, foreign-invested enterprises in the agro-processing industry suffered from high tax burden (World Bank, 1998: 58; Food and Agriculture Organization (FAO), 2011: 46).

In 2009, all agricultural products were exempt from 12 percent value-added tax, which gave an advantage to the agro-processing industry to compete at a better standing in the international market (Kaseeva, 2013: 14; IPA, 2018). Such a tax incentive could encourage FDI into Kyrgyzstan's agro-processing industry. Due to the policy reform in 2011, there is no discrimination between domestic and foreign investors in terms of legal rights, and foreigners could have 100 percent ownership of the companies. FDI flows into the agro-processing industry increased significantly to US\$4 to US\$5 million each year during 2007-2010. FDI has played a vital role in the modernization of the supply chain of Kyrgyzstan's agro-processing industry (FAO, 2011: 47, 58-59). ${ }^{2}$

Kyrgyzstan has not restricted foreign investment in energy sector and indeed has welcomed it. Selected foreign investors were given licenses by the government and these investors were guaranteed with certain favorable returns from investment in the energy sector (EBRD, 2010: 219). Meanwhile, the energy sector could not attract the foreign investors' attention until the early 2010s. FDI flows into the energy sector jumped in the mid-2010s,

\footnotetext{
${ }^{2}$ Kyrgyzstan had not been equipped with modernized supply chain, but instead the transactions occurred through open markets or bazaars. Since processing companies faced lack of investment and issues relating to the access to quality raw material, it was difficult for them to engage in long-term reliable contracts with the producers in the agro-processing industry. Even if the contracts were to be established, both the farmers and the processors violated their contracts when facing larger profit opportunity (FAO, 2011: 57-58).
} 
accounting for more than 10 percent of FDI inflows during 2015-2017.

Since 1991, Kyrgyzstan started the creation of Free Economic Zones (FEZs) and as of the mid-2010s, there are five FEZs, namely Bishkek, Maimak, Naryn, Karakol, and Leilek (UNCTAD, 2016: 16; Komendantova et al., 2018b: 11). Main goals of the FEZs are to attract investment, particularly in the form of FDI, and to bring about transfer of technology and managerial know-how (CAREC, 2018). FEZs provide investment incentives mainly in the form of tax reduction and exemption. The effectiveness of FEZs, however, is doubtful (UNCTAD, 2016: 16; Komendantova et al., 2018b: 11). Compared to 2010, exports from FEZs decreased by 39 percent in 2016 and import values exceeded export values (Komendantova et al., 2018b: 12). The fall in export values can be explained by the low total factor productivity of Kyrgyzstan which leads to a decline in competitiveness in the international market. It suggests the importance of education, skill training and technological innovation in stimulating FDI inflows in the long run (CAREC, 2018).

\subsection{Trade Policy Measures}

In 1994 and 1995, Kyrgyzstan started to pursue trade liberalization by eliminating export licensing requirements in most of the export products (World Bank, 1995). It became the first among the FSU countries to accede to the WTO in 1998 with the lowered import protection level (Zhunusova, 2017: 1; WTO, 2014: 8). With the entrance to the WTO, it removed export subsidies provided in the agricultural sector. Trade liberalization resulted in shrinkage of the share of Kyrgyzstan's agricultural sector since the mid-1990s (WTO, 2006: 61, 87).

Entrance to the WTO implies that Kyrgyzstan created an environment that is more favorable to the growth of the garment industry (Jenish, 2014: 4-5). Kyrgyzstan used a simplified weight-based customs clearance protocol, instead of an ad-valorem tariff which uses a calculation based on the percentage of imported value (World Bank, 2016: 105). The weight-based customs clearance contributed significantly to the garment industry by allowing domestic manufacturers to acquire cheaper imported fabrics compared to the past (Jenish, 2014: 5, 17).

The government of Kyrgyzstan made changes in trade policy in 2012, which included the increase in import tariff rate for some goods. Such change was designed to protect the burgeoning domestic manufacturing sector. More specifically, the tariff rate on the imported fabric increased from US $\$ 0.20$ to US\$0.35 per kilogram, leading to the increase in the price level of final garment product made by Kyrgyzstan (Jenish, 2014: 12). The increase in import tariff rate affected the domestic textile producers positively, while it affected the garment producers negatively. On the other hand, Kyrgyzstan developed strategies for export promotion of textiles and garments (OECD, 2018: 138). The donors such as the United States Agency for International Development (USAID) supported Kyrgyz garment producers' participation in the garment expos (USAID, 2017).

Kyrgyzstan acceded to the Eurasian Customs Union (ECU) in 2015 and the accession was expected to decrease the international competitiveness of certain industries of Kyrgyzstan by raising production cost of the Kyrgyz industries such as garment and agro-processing industries (Jenish, 2014: 5; Yakubovich \& Yenikeyeva, 2016: 7; Schröder \& Schröder, 2017: 4). In the process of producing garments, Kyrgyzstan depends heavily on imported fabrics, as there is almost no domestic fabric production. In joining the ECU, however, imported fabrics are treated under the common external value-based tariff, which is higher than the current weight-based tariff system according to the most-favored-nation (m.f.n.) tariff rate under the WTO system. This led Kyrgyzstan to lose price competitiveness in the international garment market by raising unit cost of the garment production in Kyrgyzstan (Jenish, 2014: 5). Thus, the accession to the ECU did not contribute to the development of certain industries such as the garment industry and agro-processing industry in the latter half of the 2010s. The import tariffs applied to most of the products in the garment industry were phased out by 2015 (World Bank, 2016: 110).

To promote exports of goods produced in the agro-processing industry, the government initiated the Action Plan for Developing Exports of the Kyrgyz Republic for 2015-2017, which emphasized four aspects. First, for the access to trade information and export promotion, the government would provide assistance to the private enterprises in participating in related exhibitions. Second, the government introduced the single window mechanism that would increase efficiency of international trade. Third, the government emphasizes the importance of meeting the international standard in terms of the quality of its agro-processed products by increasing budget funding and training private enterprises (DPCC, 2018: 34). Fourth, the government noticed the importance of providing finance to the firms (Yakubovich \& Yenikeyeva, 2016: 6).

\subsection{Strengthening Infrastructure}

Weak infrastructure constrains economic development of developing countries. Therefore, the government of Kyrgyzstan has tried to strengthen infrastructure, particularly essential in the development of the priority sectors. For instance, Kyrgyzstan's National Sustainable Development Strategy for 2013-2017 stated its plan to create 
Technopolis to promote investment, job and export of the textile and garment industry (NCSD, 2013: 105). The government assigned a single logistic center in Technopolis for both export and import. It also intended to guarantee a stable supply of energy, a better access to transportation and an efficient use of resources that minimizes unnecessary wastes (OECD, 2014: 62; International Monetary Fund (IMF), 2014: 131).

The government has also tried to improve the infrastructure to promote the agro-processing industry. It expects to establish seven regional logistic centers assigned with specific agricultural products and construct the other necessary infrastructure, such as laboratories, slaughterhouses, processing enterprises and transportation companies, for the promotion of export of the industry (DPCC, 2018: 33).

\subsection{R\&D Promotion}

The government of Kyrgyzstan did not, in general, actively pursue policies promoting technology-intensive industries. Rather, Kyrgyzstan remained to focus on developing the traditionally prioritized sectors (NCSD, 2013: 53; WTO, 2014: 100). Due to its focus on such traditional sectors, it did not have many incentives to develop knowledge-based and technology-intensive industries and to maintain high level of investment in R\&D activities (United Nations Educational, Scientific and Cultural Organization (UNESCO), 2015: 367-379). During 1997-2013, there was no significant change in the ratio of R\&D expenditure divided by GDP (UNESCO, 2019).

Meanwhile, the government of Kyrgyzstan tries to implement policies targeting technological modernization (NCSD, 2013: 69). As legal protection for intellectual property rights can provide incentives to foster technological development, the government implemented the State Program for the Development for Intellectual Property and Innovation for 2012-2016 to promote economic modernization by developing advanced technologies. Moreover, Kyrgyzstan has also tried to develop human capital that can contribute to innovation. Its expenditure on education, 6.8 percent of GDP in 2011, is in general higher than that of the other FSU countries. However, despite such investment in education, Kyrgyzstan is facing poor physical infrastructure and low quality of teachers. As a result, the government attempted to reform its educational sector by establishing National Education Development Strategy for 2012-2020 to improve quality of higher education and to increase the number of Ph.D. degree holders majoring in science (UNESCO, 2015: 369, 380).

In 2013 the government particularly developed High Technology Park (HTP), which is Kyrgyzstan's first and only facility aimed to nurture experts in the field of information technology (IT) and to foster export of such sector. To achieve such goals, HTP has engaged in cooperative education sessions with relevant institutions. HTP has its competitive advantage in accepting the small-scale orders which many large international IT companies do not emphasize (CAREC, 2018: 38). ${ }^{3}$

\section{Kyrgyzstan's Priority Sectors and Industrialization}

\subsection{Agriculture}

Kyrgyzstan specialized in wool, livestock products and cotton under the system of the Soviet Union until the 1980s. Incentives were provided to livestock and cotton producers not based on economic calculations (Khan, 2002: 7-8). In the centrally planned Soviet economy, the government of Kyrgyzstan controlled agricultural prices and there was huge amount of subsidies provided in these industries. The prices of agricultural goods were lower than those of the international market, and relative to the input prices, output prices were closer to the world prices, creating a favorable condition for the farmers (Christensen and Pomfret, 2007: 9).

With the disintegration of the Soviet Union, such irrational agricultural specialization system broke down and Kyrgyzstan liberalized prices of most goods, except for irrigation water, electricity and railway tariffs (Khan, 2002: 9; Christensen \& Pomfret, 2007: 9). With deregulation of prices, input prices, which were mostly composed of imported goods, increased more significantly than output prices and such sharp increase in input prices further increased production cost, thus reducing the profitability of the agricultural sector (World Bank, 1998: 50). The government maintained subsidies on agricultural products to alleviate the negative effect of deregulation of prices (Christensen \& Pomfret, 2007: 9).

Prior to the economic transition, like all the other FSU countries Kyrgyzstan adopted the Soviet Union's agricultural model characterized by large and state-owned farms. During the Soviet era, 98 percent of arable lands were dominated by approximately 500 collective and state-owned farms. After the independence, Kyrgyzstan's agricultural development model was changed to a market-based system, placing an emphasis on

\footnotetext{
3 There are some limitations on the HTP. One of the issues is that the age of the HTP residents is mostly below 30 years old. These young people may lack managerial experiences and be more likely to emigrate to the other countries than the elder people (CAREC, 2018: 38).
} 
the role of small- to medium-sized individual family farms (individualization) and privately owned lands (privatization). This transition led to a dramatic change in the structure of the agricultural sector. The land reform law focused on the redistribution of lands that were previously owned by the collective enterprises, encouraging the formation of new individual family farms (World Bank, 1998: 24, 42; Lerman and Sedik, 2009: 1-3). ${ }^{4}$ Thus, individualization and privatization proceeded together with deregulation in the agricultural sector of Kyrgyzstan.

Since Kyrgyzstan's agricultural production was characterized as labor-intensive relative to the other FSU countries, it could gain greater return from privatization and individualization (FAO, 2011: 42). Although sudden reform measures affected the agricultural sector negatively in the short-run in the early 1990s, the productivity in the agricultural sector increased gradually since 1996 (NSC, 2018). It could be attributed to privatization and individualization in the agricultural sector (Lerman and Sedik, 2009: 1; FAO, 2011: 9). Table 6 shows production in the agricultural sector of Kyrgyzstan. Total production of main agricultural products increased rapidly from 4.2 million tons in 1994 to 8.4 million tons in 2004. Although it stagnated during 2005-2012, it increased again in the range of 8 to 10 million tons each year during 2013-2017 (NSC, 2018).

Table 6. Output of Agriculture, Fisheries and Forestry Products by Categories of Farm

(unit: billions som)

\begin{tabular}{ccccc}
\hline Year & Collective farms & peasant (farmer) farms & Private farms & Total \\
\hline 1996 & 2.6 & 4.0 & 8.3 & 15.5 \\
2005 & 1.9 & 36.7 & 23.4 & 63.4 \\
2015 & 3.0 & 119.0 & 69.7 & 196.9 \\
2018 & 2.8 & 123.6 & 71.8 & 203.8 \\
\hline
\end{tabular}

Source: National Statistical Committee of the Kyrgyz Republic (2018). Official Statistics. Retrieved from http://stat.kg/en/statistics/selskoe-hozyajstvo/

By commodity, production of cotton increased from 52.4 thousand tons in 1992 to 118.1 thousand tons in 2005, while it decreased to 74.7 thousand tons in 2018. Tobacco production continued to decrease from 43.1 thousand tons in 1992 to 13.4 thousand tons in 2005 and then decreased further to less than 2 thousand tons each year in 2015 and 2018. Unlike the long-run tendency of decrease in the production of cotton and tobacco, production of dairy products increased. For instance, milk production increased from 961 thousand tons in 1992 to 1,590 thousand tons in 2018. Although meat production decreased from 228 thousand tons in 1992 to 182 thousand tons in 2005, it recovered since then to 221 thousand tons in 2018 (NSC, 2018).

Agricultural production, as a whole, increased rapidly during the mid-2010s, which could be partly attributed to the government's recent emphasis on the agricultural sector; according to the National Sustainable Development Strategy covering the mid-2010s, the government highlighted the importance of developing the agricultural sector (NCSD, 2013: 54). Reflecting such an emphasis on the agricultural sector, production of the food products, beverage and tobacco increased from 19.0 billion soms (11.6 percent of GDP) in 2011 to 31.8 billion soms (13.4 percent of GDP) in 2017 (NSC, 2018). Production of the agricultural sector rose as much as 66.8 percent during 2011-2017, which can be compared with the increase in the production of the industrial sector, 44.3 percent, during the same period.

\subsection{Gold Mining}

The mining sector accounted for 5 percent of national production and 10 percent of industrial production in 1991 . From 1992 to 1996, the share of the mining sector in Kyrgyzstan's GDP declined (World Bank, 1994: 1). From 1996 to 1997, there was a significant increase in its share of GDP, accompanied by the amendment of the Law of the Kyrgyz Republic on Subsoil to a more investment-friendly direction, which could be characterized as easier licensing process and less government intervention (World Bank, 2002). Foreign capital played an important role in the mining sector. About 55 percent of FDI flows into Kyrgyzstan in terms of stock was explained by the mining sector during 1995-2002 (Dikkaya \& Keles, 2006: 151).

Gold has been the most important product in the mining sector of Kyrgyzstan. After independence, the government of Kyrgyzstan established a state-owned mining company, Kyrgyzaltyn, and granted a de facto monopoly on the gold mining sector. The government was given the right to issue mining licenses and monitor mining activities. The government granted such a right to Kyrgyzaltyn and insisted investors to form a joint venture with it. Gold mining has been dominated by the Kumtor gold mine. The Kumtor gold mine project is a joint venture between Kyrgyzaltyn and Cameco Corporation. As such, the government did not privatize the mining sector until the early 2000s (World Bank, 1994: 15; World Bank, 2002: 24-26).

${ }^{4}$ As of 2008, 75 percent of arable lands were owned by individual family farms (Lerman and Sedik, 2009: 1). 
Over time, Kyrgyzstan has displayed efforts to improve ineffective and weak mining sector policy through privatization of the sector (NCSD, 2013: 96). Beginning from the mid-2000s, the government tried to minimize state involvement in the sector by decreasing its equity holdings of the state-owned mining company, Kyrgyzaltyn, from 67 percent to 33 percent in 2005 and 15.7 percent in 2014. In addition, although very generous tax incentives had been provided to Kumtor company, such benefits were reduced in 2004 (WTO, 2014: 92).

The gold mining sector accounted for 94 percent of mining income, 8 percent of GDP, and 17 percent of government revenue in 2014 (EBRD, 2017: 36; Eurasia Foundation of Central Asia (EFCA), 2017: 9). As of 2017, Kumtor alone contributed to 9.7 percent of Kyrgyzstan's GDP (Kumtor Gold Company, 2018). Meanwhile, Kyrgyzstan faces limited growth potential in the gold mining sector, as the Kumtor gold mine is expected to be depleted by 2026 (United Nations Economic Commission for Europe, 2010: 13; WTO, 2014: 92; EFCA, 2017: 9).

\subsection{Energy}

In the early 1990s, Kyrgyzstan heavily depended on the import of energy. Since Kyrgyzstan did not have a capacity for oil refinery, domestically produced crude oil was exported and the refined oil was imported back to the country (World Bank, 1993: 137). On the other hand, Kyrgyzstan has exported electricity. Electricity exports of Kyrgyzstan reached its peak in 1997 with 9.2 billion kilowatt hours (kwh). Electricity exports fell sharply to between 1 and 3 billion kwh each year during 1998-2012 and decreased further to less than 1 billion kwh each year during 2013-2016 (Knoema, 2016). Since the 1990s up to the present, Kyrgyzstan's export of energy is mostly attributable to hydroelectricity (World Bank, 1993: 137; World Bank, 2017). Hydro energy accounted for 53 percent in Kyrgyzstan's total energy resources, 2 percent of GDP and 16 percent of industrial output in 2013 (NCSD, 2013: 90).

Kyrgyzstan's hydroelectricity production has been closely linked to the demand of the other FSU countries, since Kyrgyzstan and these countries use common power grid in the Central Asian Power System (CAPS) and these countries require hydro power for irrigation. Kyrgyzstan also relies on Uzbekistan and Kazakhstan's electricity transmission line to provide energy across its nation (World Bank, 1993: 139; Asian Development Bank (ADB), 2013: 2).

Hydroelectric power has significant potential for growth in Kyrgyzstan, as less than 10 percent of the resource was utilized as of the late 2000s (EBRD, 2010: 223). Thus, the energy sector, including hydro power, is considered as one of the important priority sectors for Kyrgyzstan. In developing hydroelectricity, small hydro power plants are considered as the most attractive source of renewable energy, as they can lead to wider distribution of energy throughout the nation (NCSD, 2013: 90; Komendantova et al., 2018a: 4, 10).

\subsection{Garment Industry}

With the disintegration of the Soviet Union that disrupted the entire supply chain, the overall share of the industrial sector declined and did not return to the level in 1992, i.e. 36.0 percent of GDP (UNCTAD, 2019). Garment industry was not an exception to such a downfall of the manufacturing sector. During the transition period, the government of Kyrgyzstan focused on privatizing economic activities, and liberalizing market and international trade. The privatization of companies led to a shift from large factories to multiple small- to medium-sized enterprises (SMEs). It also led the companies to be vulnerable, as they were unable to realize economies of scale, to upgrade technologies from the Soviet period, and to attract sufficient investment for themselves to function well. As a result of trade liberalization, these privatized companies were to face highly competitive international market and many companies were bankrupt (Abylaev, 2013).

During the 1990s Kyrgyzstan's exports of garments decreased from US\$7 million in 1995 to US\$3 million in 2000. Garment industry began to develop since the mid-2000s. For instance, garment exports increased to US\$23 million in 2005 and then to over US\$100 million each year during 2010-2013 (UN Comtrade, 2018). The reason behind this impressive growth in the garment industry since the mid-2000s is Kyrgyz government's implementation of the industrial policy that specifically promoted its garment industry (Jenish, 2014: 4). Garment exports remained between US\$40 million and US\$70 million each year in 2015 and 2016, while export values of garments recovered to US\$119 million in 2017 (UN Comtrade, 2018).

Although Kyrgyzstan's garment industry had been growing in the early 2000s, production and export of the industry started to decline after reaching its peak in 2012, in terms of export value. The main reasons for the decline in the garment industry are the increase in the competition with foreign producers and the implementation of more strict requirements to Kyrgyzstan's products imposed by the main importers, namely 
Russia and Kazakhstan (Komendantova et al., 2018a: 14). Kyrgyzstan faces several problems hindering the growth of the garment industry, such as poor operational management skills, lack of advanced technologies and equipment, limited energy security and corruption. In addition, more than 50 percent of the garment producers in Kyrgyzstan have difficulties in financing and three-quarters of them claimed that interest rates are too high (World Bank, 2016: 100, 122-123). Due to low labor productivity, Kyrgyzstan indeed ranked 113th out of 137 countries for labor market efficiency in 2017 (Rovenskaya et al., 2018: 10, 23).

\subsection{Agro-processing Industry}

Agro-processing industry adds value to outputs produced in the agricultural sector. The government considers that Kyrgyzstan has ideal conditions to develop agro-processing industry, as the country has a favorable climate, fertile land, mass production of raw materials, and abundant and relatively cheap labor force (Ministry of Agriculture of the Kyrgyz Republic, 2006: 2). The agro-processing industry, however, showed mixed results depending on products. For instance, production of mineral water, non-alcoholic drinks, and beer increased, while that of bread, tobacco, and alcoholic drinks, excluding beer, decreased during 1996-2017 (Komendantova et al., 2018a: 17).

The government has stressed the importance of export promotion of the agro-processing industry, but the industry faces some problems. One of the problems is the agro-processing industry's not having sound equipment and infrastructure. Equipment in the agro-processing industry is physically decayed and technologically outdated, which leads to inefficient production, thus decreasing the competitiveness of the agro-processing industry in the international market (Komendantova et al., 2018a: 9).

The government plans to develop the agro-processing industry by promoting international trade, creating logistical centers for agricultural and agro-processed products, and encouraging cooperative works between different sectors of agriculture (Ministry of Agriculture of the Kyrgyz Republic, 2006: 2; Komendantova et al., 2018a: 17). Under the Development Program of the Kyrgyz Republic for the period 2018-2022, the government aims to support the agro-processing industry. Priorities will be given to the increase of overall production level of domestically processed products, the creation of medium and large processing complexes, and the provision of more effective means of logistic centers (DPCC, 2018: 32). In addition, to facilitate the financing needed in the development of this industry, the government plans to simplify the financing approval process and to establish an insurance system (Komendantova et al., 2018a: 17). International organizations contributed significantly in supporting the development of Kyrgyzstan's agro-processing industry by providing financial aid, technical support, and consulting (Kaseeva, 2013: 15).

The share of food, particularly products belonging to the agro-processing industry, in total exports, equaled 22.8 percent in 1995, while it decreased to 11.7 percent in 2005. It recovered to 18.2 percent in 2015 and 20.0 percent in 2017, respectively (World Bank, 2018). Tobacco and dairy products have been noteworthy in exports. Tobacco exports remained between US\$20 million and US\$35 million in general during 1995-2017 and equaled US\$22 million in 2017. During the 2000s and 2010s, exports of dairy products increased, reaching US\$37 million in 2017 (UN Comtrade, 2018).

\section{Policy Implications}

Kyrgyzstan pursued the market-based reform since the independence. Starting from the second half of the 1990s, it recorded positive economic growth rate. In the meantime, the government of Kyrgyzstan selected several priority sectors and tried to promote those industries by various industrial policy measures. The experience of the industrial policy and industrialization of Kyrgyzstan in the process of transition provides certain policy implications to the other transition economies, and developing countries in general, as well as Kyrgyzstan.

Among other FSU countries, the government of Kyrgyzstan took the big bang approach in the transition process. The pursuit of sudden deregulation of price level right after the independence led to hyperinflation in Kyrgyzstan in the early 1990s. It reveals one of the serious problems of pursuing the big bang approach in the transition, i.e. abrupt across-the-board deregulation of price level may lead to chaotic situation, particularly in the inflation rate.

After experiencing serious depression for three years, the economy began to recover since 1996 and the government of Kyrgyzstan pursued development of several selected sectors by implementing industrial policy; the government has provided tax incentives to the garment industry and the agro-processing industry. Although the provision of tax incentives may contribute to the promotion of the industries concerned, it may be accompanied by costs such as tax revenue forgone (ILO, 2012). Some of the tax incentives provided by Kyrgyzstan appear to be inefficiently designed. Patent-based tax system applied in the garment industry benefits relatively larger enterprises in the sense that tax payment is not based on production values. In addition, tax and 
financial incentives provided by the government are regulated by the WTO system. That is, if the products provided with such incentives were exported, then those products may be subjected to countervailing duties by the government of the importing country or, alternatively, such subsidies may be prohibited by the WTO, depending on the situation. ${ }^{5}$ Therefore, tax incentives used as the industrial policy measure should be used carefully in light of the regulations of the WTO system, particularly the Subsidies Code of the WTO.

The government of Kyrgyzstan pursued trade liberalization, which lowered import tariff rates in general. The accession to the WTO in 1998 laid the foundation of trade expansion. Despite the contribution of trade liberalization policy in reducing the production cost of outputs and in utilizing imported raw materials and intermediate products, certain trade policy measures appear to be inappropriately designed. For instance, the accession to the ECU in 2015 did not contribute to the development of the manufacturing sector such as the garment industry, as the import tariff imposed on fabric import increased since then. Such an increase in import tariff rate on imported fabric negatively affected the development of the garment industry. Therefore, in trade policy formulation, the government of Kyrgyzstan needs to be more alarmed in the potential effect of trade policy changes on the development of the manufacturing sector.

The government of Kyrgyzstan has realized the importance of the pursuit of trade liberalization and FDI inflows in economic development. Therefore, it strengthened its effort in attracting FDI. Reflecting such an active government policy to attract FDI, FDI flows into Kyrgyzstan increased rapidly since the mid-2010s. Active investment-friendly government policy appears to have laid the foundation of FDI inflows. Meanwhile, during 2015-2017, the share of the manufacturing sector in FDI inflows remained between 30 percent and 36 percent. That is, there is much room for attracting FDI into the manufacturing sector. Although the FEZs have been mainly established to attract foreign investors, their role in attracting FDI and export weakened during the 2010s. Mere reliance on the low wage level may not lead to further FDI flows into the FEZs any longer. Consequently, improvement of productivity by strengthening human capital, for instance, is needed for further development of the FEZs.

Despite the government's official position of trying to improve the level of technology and human capital, R\&D expenditure/GDP ratio fell from about 0.2 percent during 1997-2013 to 0.1 percent during 2014-2016 (UNESCO, 2019). It shows that the economic policymakers are not fully aware of the importance of $R \& D$ in upgrading the technology level in economic development. For instance, Kyrgyzstan's case can be compared with the case of Korea, which leapfrogged from one of the least developed countries in the 1960s to one of the developed countries in the 2010s. In the process of rapid economic growth, the Korean government continued to emphasize and support science and technology (Mah, 2007). It has also been the case of two other rapidly growing East Asian economies, i.e. China and Taiwan (Kim \& Mah, 2009; Mah, 2015). It is necessary to refer to the experience of the active $R \& D$ promotion policy in the development of value-added technology intensive industries and rapid economic growth of those East Asian economies.

Selecting the priority sector is critical in industrial policy. The government of Kyrgyzstan designated several priority sectors. Agriculture has been one of those priority sectors. Farmers had been over-protected under the Soviet economic system. In addition, Kyrgyzstan had been allocated the role of providing certain agricultural commodities in the supply chain of the Soviet Union, although such a role had not been based on rational calculation. Emphasis on the role of individual farmer rather than collective farming and privatization of the agricultural sector led to an increase in productivity since the late 1990s. The share of the agricultural sector rose in the 2010s, as the government of Kyrgyzstan emphasized the agricultural sector in the 2010s. The government's emphasis on the agricultural sector may not be appropriate from the viewpoint of the long-run economic development of Kyrgyzstan; there is little evidence of Kyrgyzstan's comparative advantage in the agricultural sector, which is in general regarded as relatively low value-added. Thus, before simply adhering to the promotion of its traditional priority sectors, it would be needed for the government of Kyrgyzstan to reconsider the direction of industrial policy.

The government of Kyrgyzstan chose (gold) mining as another priority sector and provided incentives, including tax incentives, to encourage investment in the sector. As of 2019, however, it appears that the incentive is not appropriate in the sense that gold mining production is expected to disappear from Kyrgyzstan by 2020 s. Provision of tax incentives implies tax revenue forgone and, therefore, those incentives should have been allocated to industries more promising in the long run.

Due to the geographical condition, Kyrgyzstan is competitive in hydroelectricity generation. Kyrgyzstan's

\footnotetext{
${ }^{5}$ Refer to Mah (2010) for the details on the WTO regulations on tax and financial incentives affecting developing countries.
} 
hydroelectricity production has been closely linked to the demand of the other FSU countries. Since Kyrgyzstan also relies on the electricity transmission line of the neighboring countries, from the viewpoint of economic development and export of hydroelectricity, it is essential for Kyrgyzstan to maintain peaceful diplomatic relations with the neighboring countries.

Despite the government's constant effort to promote the garment industry, it can be said that the effect of the government's industrial policy to promote the garment industry has been negatively offset by the lack of skilled workforce, technology and infrastructure. Thus, it is vital for Kyrgyzstan to focus on nurturing better qualified human capital through appropriate job training and improvement of outdated production facilities. In addition, as is shown in the unsatisfactory performance of FDI inflows in Kyrgyzstan's garment industry, promotion of the garment industry, which relies on low wage level, may not be appropriate in the near future stage of economic development. Therefore, it is necessary for the government of Kyrgyzstan to pay attention to development of more value-added textile industry and other promising industries in the manufacturing sector.

The agro-processing industry has also been designated by the government of Kyrgyzstan as one of the priority sectors. Although the government has been providing subsidies and tax incentives to promote the industry, the level of FDI still remains low, and the quality of infrastructure and products are not satisfactory. The standards set for food by ECU could be used as a guideline for Kyrgyzstan to foster the development of its agro-processing industry. Moreover, creating a stable and reliable interdependent relationship between agriculture and agro-processing industry is vital. Such a relationship can further create a favorable environment for the development of agro-processing industry in gaining international competitiveness.

The government of Kyrgyzstan did not overall pursue consistent government policies that would foster its economic growth after the independence (NCSD, 2013: 5). One may say that overall the government of Kyrgyzstan has not pursued well-designed industrial policy. Although the government chose agriculture as the priority sector, it is difficult to say that Kyrgyzstan's agricultural sector can compete against that of many other developing countries internationally. In addition, although the government of Kyrgyzstan provided tax incentives to develop the mining sector until the early 2000s, the gold mining in Kyrgyzstan is expected not to provide revenue to the economy a few decades later. The government implemented policy measures to promote the garment industry, which has led the manufacturing sector. Meanwhile, lack of proper infrastructure and training programs, low volume of FDI, and its accession to ECU affected the industry negatively. Furthermore, Kyrgyzstan is expected to enter the stage of losing comparative advantage in the garment industry in the coming decades.

Therefore, it is needed for the government of Kyrgyzstan to select a few promising and more value-added industries, and to build infrastructure supporting the industries from the viewpoint of long run economic development. For instance, the efforts of R\&D promotion to develop more value-added technology-intensive industries are necessary. The government's continuing efforts of promoting the investor-friendly environment would contribute to further economic growth of Kyrgyzstan.

\section{Conclusion}

Kyrgyzstan pursued the big bang approach in the process of transition. It experienced negative economic growth and hyperinflation for three years since its independence. Since the second half of the 1990s, it could recover and record positive economic growth rates. The government of Kyrgyzstan tried to promote several priority sectors including agriculture, mining, energy, garment and agro-processing industry by industrial policy measures, which comprised tax incentives as well as measures to attract FDI. Although the government has tried to promote agriculture and mining, there is little evidence that Kyrgyzstan has a comparative advantage in the agricultural sector. Although gold mining has played an important role in exports of Kyrgyzstan, the gold mine is expected to deplete soon. Kyrgyzstan appears to be competitive in hydroelectricity generation.

The garment and agro-processing industries have been promoted by the government of Kyrgyzstan as the priority sectors. The agro-processing industry appears to be appropriate in the sense that it is located between agriculture and the manufacturing sector, while it may not lead to the development of the manufacturing sector as a whole. Although the garment industry has led the manufacturing sector of Kyrgyzstan, it has not succeeded in attracting foreign investors in the 2010s. It implies that the garment industry relying on low wage level has been losing the foreign investors' attention. Since relying just on low wage level may not lead to industrial-led economic development of Kyrgyzstan in the sense that there are many developing countries with a similar level of economic development trying to promote the garment industry. It would be needed for the government of Kyrgyzstan to think of the next stage of economic development with the new industrial policy.

As of the current stage of economic development, it would be needed for the government of Kyrgyzstan to think 
of developing value-added industries rather than adhering to the traditional priority sectors. For such value-added industries to develop, strengthening infrastructure in human capital would be critical. The government needs to refer to the experience of the East Asian economies which could develop rapidly from economies exporting garments to economies exporting value-added products belonging to technology-intensive industries. This paper has some limitations. For instance, the conclusion drawn from the case of Kyrgyzstan may be applied to neither developing countries in different level of economic development nor non-transition economies. Therefore, it would be necessary for future works to deal with the countries in various stages of economic development. In addition, as a referee suggested, this paper may be extended to cover the environmental aspects of sustainability, as is shown in Pourhejazy and Kwon (2016), for instance.

\section{References}

Abylaev, M. (2013). Kyrgyz Textile Companies'Resilience Features in the Post-Soviet Regionalization Processes. Presented at the 13th AUTEX World Textile Conference, Dresden, 22-24 May 2013.

Appel, H. (2004). A New Capitalist Order: Privatization and Ideology in Russia and Eastern Europe. Pittsburgh: University of Pittsburgh Press.

Asia Development Bank (ADB). (2013, August). Kyrgyz Republic: Country Partnership Strategy (2013-2017). Retrieved from https:/www.adb.org/documents/kyrgyz-republic-country-partnership-strategy-2013-2017

Bae, E. Y., \& Mah, J. S. (2019). The Role of Industrial Policy in the Economic Development of Uzbekistan. Post-Communist Economies, 31(2), 240-257. https://doi.org/10.1080/14631377.2018.1443252

Central Asia Regional Economic Cooperation Program (CAREC). (2018, April 1). A Diagnostic Study of Kyrgyz Republic's Free Economic Zones and Industrial Parks. Retrieved from https://www.carecprogram. org/?publication=diagnostic-study-kyrgyz-republic-free-economic-zones-industrial-parks

Christensen, G. N., \& Pomfret, R. (2007). Distortions to agricultural incentives in the Kyrgyz Republic. The World Bank. Retrieved from http://documents.worldbank.org/curated/en/818581468339615885/Distortionsto-agricultural-incentives-in-the-Kyrgyz-Republic

Dabrowski, M., \& Antczak, R. (1994). Economic Reforms in Kyrgyzstan. Center for Social and Economic Research.

Development Partners' Coordination Council (DPCC). (2018). Development Program of Kyrgyz Republic “Unity, Trust, Creation" for the Period 2018-2022. DPCC.

Dikkaya, M., \& Keles, I. (2006). A Case Study of Foreign Direct Investment in Kyrgyzstan. Central Asian Survey, 25, 149-156. https://doi.org/10.1080/02634930600903213

Eurasia Foundation of Central Asia (EFCA). (2017, December 11). Guidebook for Conflict Management in Mining Industry of the Kyrgyz Republic.

European Bank for Reconstruction and Development (EBRD). (2010). Kyrgyz Republic Energy Sector Assessment. Retrieved from https:/www.ebrd.com/documents/legal-reform/kyrgyz-republic-energy-sectorassessment-2010.pdf

EBRD. (2014). Transition Indicators.

EBRD. (2017). EBRD Extractive Mining Industries Strategy: 2018-2022.

EBRD. (2019). Forecasts, Macro Data, and Transition Indicators.

Food and Agriculture Organization of the United Nations (FAO). (2011). The Kyrgyz Republic, Opportunities and Challenges to Agricultural Growth. Retrieved from http://www.fao.org/3/a-i2711e.pdf

International Labor Organization (ILO). (2012, June 11). Skills for Trade and Economic Diversification in the Kyrgyz Garment Sector. Retrieved from https://www.ilo.org/employment/Whatwedo/Publications/ employment-reports/WCMS_182791/lang--en/index.htm

International Monetary Fund (IMF). (2014, August). The Kyrgyz Republic: Poverty Reduction Strategy Paper. Retrieved from https://www.imf.org/external/pubs/ft/scr /2014/ cr14247.pdf

Investment Promotion and Protection Agency of the Kyrgyz Republic (IPA). (2018). Agro-Industrial Sector. Retrieved from http://www.invest.gov.kg/en/about-kyrgyzstan/priority-sectors/agro-industrial-sector

Jenish, N. (2014). Export-driven SME Development in Kyrgyzstan: The Garment Manufacturing Sector. Institute of Public Policy and Administration Working Paper, 26, 1-15. https://doi.org/10.2139/ssrn.2945944 
Kaseeva, G. (2013). Processor Driven Integration of Small Farmers into Value Chains in Kyrgyzstan. Food and Agriculture Organization (FAO). Retrieved from http://www.fao.org/3/a-au849e.pdf

Khan, A. R. (2002). Macroeconomic Policies, Growth and Poverty Reduction in Kyrgyz Republic. United Nations Development Progamme.

Kim, M., \& Mah, J. (2009). China's R\&D Policies and Technology-intensive Industries. Journal of Contemporary Asia, 39(2), 262-278. https://doi.org/10.1080/ 00472330902723832

Knoema. (2016). Kyrgyzstan - Total Electricity Exports. Retrieved from https://knoema.com/atlas/Kyrgyzstan/topics/Energy/Electricity/Electricity-exports

Komendantova, N., Atakanov, N., Chekirbaev, U., Karabashov, N., Zheenaliev, Z., ... Rodriguez, F. S. (2018a). Industrial Development of Kyrgyzstan: Required Infrastructure and Priority Industrial Sectors. IIASA.

Komendantova, N., Sizov, S., Chekirbaev, U., Rovenskaya, E., Strelkovskii, N., ... Rodriguez, F. S. (2018b). Industrial Development of Kyrgyzstan: Investment and Financing. International Institute for Applied Systems Analysis (IIASA).

Kumtor Gold Company. (2018). Contribution to the Economy. Retrieved from https://www.kumtor.kg/en/mediarelations/contribution-to-the-kyrgyz-economy/

Lerman, Z., \& Sedik, D. (2009). Agrarian Reform in Kyrgyzstan: Achievements and the Unfinished Agenda. FAO.

Linn, J. (2004). Economic (Dis)Integration Matters: The Soviet Collapse Revisited. The Brookings Institution.

Mah, J. (2007). Industrial Policy and Economic Development: Korea's Experience. Journal of Economic Issues, 4l(1), 77-92. https://doi.org/10.1080/00213624.2007.11506996

Mah, J. (2010). Government-led Export Promotion in Light of Distributional Fairness in the Global Trading System. Journal of Economic Issues, 44(4), 877-894. https://doi.org/10.2753/JEI0021-3624440402

Mah, J. (2015). R\&D Policies and Development of Technology-Intensive Industries of Taiwan. Progress in Development Studies, 15(2), 125-138. https://doi.org/10.1177/1464993414565532

Ministry of Agriculture of the Kyrgyz Republic. (2006). Export Promotion Strategy for the Food Processing Industry of the Kyrgyz Republic. Retrieved from http://www.intracen.org/export-strategy-map/export-promo tion-strategy-for-the-food-processing-industry-of-the-republic-of-kyrgyzstanfood-industrySESITC-2006/

National Council for Sustainable Development of the Kyrgyz Republic (NCSD). (2013). National Sustainable Development Strategy for the Kyrgyz Republic, for the period of 2013-2017. Retrieved from http://www.lse.ac.uk/GranthamInstitute/wp-content/uploads/laws/4242_EN.pdf

National Statistical Committee of the Kyrgyz Republic (NSC). (2018). Official Statistics. Retrieved from http://stat.kg/en/statistics/selskoe-hozyajstvo/

Niazaliev, O. (2004). Failed Democratic Experience in Kyrgyzstan: 1990-2000. Middle East Technical University.

Observatory of Economic Complexity (OEC). (2015). What is the Trade Balance for Kyrgyzstan to China? Retrieved from https://atlas.media.mit.edu/en/visualize/line/hs92/show/kgz/chn/all/1995.2015/

Organization for Economic Co-operation and Development (OECD). (2014). Expanding the Garment Industry in the Kyrgyz Republic. Private Sector Development Policy Handbook. OECD.

OECD. (2018). Enhancing Competitiveness in Central Asia. OECD.

Pak, M. (2016). Former Soviet Union Countries at Twenty-five: Social and Economic Trends. ERA Institute.

Pourhejazy, P., \& Kwon, O. (2016). A Practical Review of Green Supply Chain Management. Journal of International Logistics and Trade, 14(2), 156-164.

Rovenskaya, E., Sedighi, E., Komendantova, N., Strelkovskii, N., Sizov, S., ... Rodriguez, F. S. (2018). Industrial Development of Kyrgyzstan: Background. IIASA.

Schröder, P., \& Schröder, E. (2017). Entrepreneurship in Kyrgyzstan: Adjustments to a Changing Economic Environment. Friedrich-Ebert-Stiftung.

Svejnar, J. (2002). Transition Economies: Performance and Challenges. The Journal of Economic Perspectives, $16(1), 3-28$. 
United Nations (UN) Comtrade. (2018). Trade Statistics. Retrieved from https://comtrade.un.org/data

United Nations Conference on Trade and Development (UNCTAD). (2016). Investment Policy Review Kyrgyzstan. UNCTAD.

UNCTAD. (2019). Data Center. Retrieved from http://unctadstat.unctad.org/wds

United Nations Economic Commission for Europe. (2010). Country Profiles on the Housing Sector - Kyrgyzstan. United Nations.

United Nations Educational, Scientific and Cultural Organization (UNESCO). (2015). UNESCO Science Report: Towards 2030. Retrieved from https://en.unesco.org/unesco_science_report

UNESCO. (2019). Statistical Data. Retrieved from http://data.uis.unesco.org/\#

United States Agency for International Development (USAID). (2017). USAID Supports Kyrgyzstan's Apparel Industry Debut in Paris, Program Update, Kyrgyz Republic. Retrieved from https://www.usaid.gov/ kyrgyz-republic/program-updates/oct-2017-usaid-supports-kyrgyzstans-apparel-industry-debut-paris

Uzagalieva, A. (2003). Price Liberalization, Inflation, and Regulated Prices in the Kyrgyz Republic: An Econometric Analysis. Retrieved from https://www.cerge-ei.cz/pdf/wbrf_papers/A_Uzagalieva_WBRF_ Paper.pdf

World Bank. (1993). Kyrgyzstan: The Transition to a Market Economy.

World Bank. (1994). Kyrgyz Republic Mining Sector Review.

World Bank. (1995). Kyrgyz Republic Agricultural Policy Review.

World Bank. (1998). Kyrgyz Republic Agricultural Policy Review. Strategy for Rural Growth and Poverty Alleviation.

World Bank. (2002). Kyrgyz Republic Update on the Mining Sector.

World Bank. (2016). Competitiveness of the Kyrgyz Economy in the Wake of Accession to the Eurasian Customs Union: Selected Issues and Opportunities.

World Bank. (2017). Analysis of the Kyrgyz Republic's Energy Sector - Final Report. World Bank Energy and Extractive Gold Practice ECA region.

World Bank. (2018). World Development Indicators.

World Trade Organization (WTO). (2006). Trade Policy Review: Report by the Secretariat - Kyrgyz Republic.

WTO. (2014). Trade Policy Review: Report by the Secretariat - Kyrgyz Republic.

Yakubovich, E., \& Yenikeyeva, Z. (2016). Sustainable Development of Agro-Industrial Sector and Food Security of the Kyrgyz Republic in the Process of Integration into the Eurasian Economic Union. Cornell University.

Zhunusova, E. (2017). Agricultural Development in the Kyrgyz Republic: The Impact of Domestic Policies, Changing Macroeconomic Conditions, and International Migration. Retrieved from http://geb.uni-giessen.de/geb/volltexte/2018/13440/pdf /ZhunusovaEliza_2017_10_26.pdf

\section{Copyrights}

Copyright for this article is retained by the author(s), with first publication rights granted to the journal.

This is an open-access article distributed under the terms and conditions of the Creative Commons Attribution license (http://creativecommons.org/licenses/by/4.0/). 